\title{
EFFECT OF SOME NATURAL COMPOUNDS ON YIELD, BULB QUALITY AND DISEASES CONTROL OF TWO ONION CULTIVARS GROWN UNDER SANDY SOIL CONDITIONS
}

\author{
M.M. Arafa, H.A. Abdel-Aal, S.I. Shaheen and M. H. Al Hanafy \\ Dep. of Sustainable Development of Environment and Management of its Projects \\ Environmental Studies and Research Institute, Univ. of Sadat City, Egypt.
}

Received: Mar. 1, 2016

Accepted: May 22, 2016

\begin{abstract}
Two field experiments were carried out during the two successive winter growing seasons of 2013 and 2014at the Experimental Farm of the Environmental Studies and Research Institute, University Sadat City to study the effect of natural ores and foliar spray treatments on bulb yield and its components, chemical composition, bulb quality as well as phytopathology of two onion (Allium cepa L.) cvs. Giza 20 Giza Red grown under sandy soil conditions. Natural ores treatments (mixed) were added to the soil before planting at rates of $500 \mathrm{~kg}$. per fed., while the foliar spray treatments were sprayed in growth season with recommended dose as follows, Biophertel Ore at $10 \mathrm{~cm}^{3} /$ letter, Biocide Ore at $5 \mathrm{~g} /$ letter, Bentocide Ore at $10 \mathrm{~g} /$ letter, Ammonium nitrate liquid (33\%)at 0.5 liter / $50 \mathrm{~L}$ of water. A randomized complete blocks design with three replicates was used.

The results showed that, cv. Giza 20 significantly gave the highest values in most of all tested parameters i.e., yield and yield components, bulb quality, mineral contents of bulbs as well as phytopathology than cv. Giza Red during both seasons. In addition, fresh weight of bulb, total yield per fed., marketable yield, quality of bulbs (mean shape index, number of episode circular and T.S.S \%) and chemical composition of bulbs were significantly increased by using natural ores (abd+mix.), while phytopathology significantly affected by adding natural ores mixed at the soil than other

treatments.

The interaction between the cultivars and natural ores was not significantly effected in all parameter of study in both seasons.
\end{abstract}

Key words: Biophertel, Biocide, Bentocide, Bulb quality, Chemical constituents.

\section{INTRODUCTION}

Onion (Allium cepaL.) is a globally famous vegetable used in a many variety of ways, including eaten fresh, added as a spice or prepared as a main ingredient in cooking. Pungent taste, sweet taste, texture and several other qualities are required for onions to be suitable as processing ingredients. These qualities are influenced by the metabolite composition. Egyptian onions as an important export crop and through the study of the most important importing markets and the factors influencing them, the production of onions loop winter and summer and the Nile represents about $79.1 \%, 13.06 \%, 7.85 \%$, respectively of the total domestic production of onions, amounting to about 2226.15 tons on average for the period (2007-2014). Egyptian onion is exported to many countries of the world and this crop is greatly desired for its good quality and early appearance in the foreign markets. Many agricultural practices judge the productivity of onion yield among these chosen high yielding cultivars, mineral and organic fertilization and transplanting dates,

Organic fertilizer is considered as an important source of humus, macro and micro elements carrier and increase the activity of 
the useful microorganisms (El-Gizy, 1994). Addition of organic fertilizer improves soil structure, which can encourage root development and leads to encourage growth (Singer et al., 1998). Onion rightly called "queen of kitchen" is one of the oldest known and important crop grown in Egypt and many countries of the world. In addition, it has been reported to be rich in phytochemicals especially medicinal flavones (Javadzadeh et al., 2009). Mostafa and Abd El-Megid (1998) found that cv.Yellow Creole and Composite 16 had heaviest bulb and marketable yields/fed. whereas cv. DMR and cv Ori produced lowest marketable yield/fed.cvs Composite 9 and Yellow Creole produced the highest culls yield Meanwhile cvs Hazera 8 and DMR produced the lowest culls yield /fed. Giza 20, Behairy No Pink and Composite 16 cvs were superior in total soluble solids and dry matter content, whereas cvs Ori, Hazera 8, Beth Alfa and Yellow Creole. were the lowest. Ori and Hazera 8 cvs had the highest total loss in bulb weight during storage period of four months.Abd EL-Salam et al.(2005)found that the most effective treatment of the capaicin vitamin yield, total uptake content of macro elements (N,P and $\mathrm{K})$ and micro - elements ( $\mathrm{Zn}, \mathrm{Cu}$ and $\mathrm{B})$ they found that increased with increasing the level of rock phosphate at rate $60 \mathrm{~kg} / \mathrm{fed}$. and minerals earth at rate $30 \mathrm{~kg} / \mathrm{fed}$. a well as their combination.

Abo-Koreen and Arafa (2005) studied the effect of three levels of compound mineral fertilizer i.e. 0,40 and $80 \mathrm{~kg} \mathrm{NPK}+$ micro elements /ha. on the vegetative growth, yield and its components and quality on two onion cultivars (Red Amposta and Texas Yellow Grano 502). Results showed that Red Amposta cultivar was generally superior to Texas Yellow Grano 502 in terms of growth, yield and quality. Highest level of compound fertilizer $(80 \mathrm{~kg} / \mathrm{ha}$.) recorded the highest values of bulb weight, total yield, marketable yield, percentage of dry matter, while cv. texs Yellow Grano 502 with the third level of mineral compound fertilizer increased percentage of early flowering and percentage of double bulbs.

Al-hefny et al. (2008) showed that, the application of magnetite at the rate of 200 $\mathrm{kg} / \mathrm{fed}$. produced the highest value of curd fresh weight and the highest total yield /fed. when compared to no magnetite application treatment. Kandil et al. (2010) indicated that cvs. Giza 20 and Composite 9 had the heaviest bulb weight, followed by Giza Red. They also found that highest percentages of T.S.S and dry matter \% were obtained from Giza White, followed by Giza 20. Giza 20 cultivar was associated with maximum total bulbs yield and marketable yield followed by Composite 9.

Salem (2012) concluded that fertilization onion plants with $50 \% \mathrm{NPK}+50 \% \mathrm{FYM}$ and spraying with A grispon + EM increased onion yield over the control (100\% NPK without foliar applications) and improved bulbs quality. Hence, this treatment is recommended where the mineral fertilization is reduced to $50 \%$ and this in turn decreases the environment pollution and production costs.

Soleymani and Shahrajabian (2012) investigated the effects of four levels of nitrogen (0,100, 200 and $300 \mathrm{~kg} \mathrm{~N} / \mathrm{ha}$.) on yield and nitrate content of four spring onion cultivars (Cisakht, Dorche, Esfahan and Swit Spanish). They stated that foliage fresh weight, bulbing ratio, plant length, weight of bulb, total yield, favorite yield, total percentage of dry matter and nitrate content in bulb were significantly influenced by cultivars and the maximum values of these traits were resulted from Cisakht cultivar.

Several factors have been identified for the low productivity of onion in Egypt, the most important factors responsible are the diseases like Downy mildew, Purple blotch, 
Stemphylium blight, White rot, Basal rot, storage rots and non-availability of varieties resistant to biotic and a biotic stresses. Downy mildew of onion caused by Peronospora destructor [Berk.] Casparyand Purple blotch caused by Alternaria porri (Ellis)Cif. are the most prevalent and dangerous foliar diseases worldwide and cause the major problems of onion production in Egypt (Abd El-Moity et al., 1997; Abdel-Megid et al., 2001).

However, yield losses reached $75.11 \%$ in case of Downy mildew and $97.3 \%$ in case of Purple blotch (Lakra,1999) and (Jayakumaret al., 2008). These losses mainly result from severe infections in bulb onion crops causing early defoliation, reduced bulb sizes, and poor storage quality of bulbs (Survilieneet al., 2008). Downy mildew can cause serious losses within a short period of time during cool and humid weather conditions (Hoffmann et al., 1996). High relative humidity up to $100 \%$ and temperature range from 20 to $28^{\circ} \mathrm{C}$ were optimum for infection purple blotch (Kumar, 2007).

There for the aim of this study was to determine the effect of natural ores treatmentson yield and its components, quality, chemical composition andphytopathology on two onion (Allium cepa L.) cvs Giza 20 Giza Redgrown under sandy soil conditions.

\section{MATERIALS AND METHODS}

Two field experiments were carried out during the two successive winter growing seasons of 2013 and 2014 at the Experimental Farm of the Environmental Studies and Research Institute University of Sadat City to study the effect of natural ores treatments on yield and its components, , chemical composition and bulb quality as well as phytopathology of two onion (Allium cepa L.) cvs. i.e., Giza 20 and GizaRed grown under sandy soil conditions. Natural ores treatment (mixed) were added to soil before planting at rates of $500 \mathrm{~kg}$. / fed. , while foliar spray treatment weresprayed with the recommended dose as follows, Biophertel Ore at $10 \mathrm{~cm} / \mathrm{L}$., Biocide Ore at $5 \mathrm{~g} / \mathrm{L}$. , Bentocide Ore at $10 \mathrm{~g} / \mathrm{L}$. , Ammonium nitrate liquid (33\%) at 0.5 liter / $50 \mathrm{~L}$. of water.

Random sample of soil were taken before planting for physical and chemical analysis Table ,1. The texture of experimental farm was sandy in texture. The procedures used were described by means of Jackson (1965). Analysis of irrigation water used is given in Table 2. Metrological data during two seasons at Sadat City are given in Table 3.

Table 4 Chemical analyses of natural ores (mixed minerals ore), Biocide Ore, Bentocide Ore and Biophertil .

A randomized complete blocks design with three replicates was used. The natural ores individual or compound were situated in the subplots while cultivars were randomly distributed in main plots. The sub-plot area was $\left(3^{*} 3.5^{*} .9\right)=9.45 \mathrm{~m}^{2}$ the plants were grown in the field on ridges of $90 \mathrm{~cm}$ width at $10 \mathrm{~cm}$ apart, seeds of two onion cultivars were sown in nursery on $1^{\text {st }}$ October while transplanting took place on $15^{\text {th }}$ December of both seasons. The experiment was divided into 54 experimental piece is two classes. Class I ( Giza 20 ) contains 27 pieces and Class 2 ( Giza Red) contains 27pieces by using mixture of natural ores and organic spraying treatments, by using mixture of natural ores and organic spraying treatments,1. Biophertel ore + mix. Ore (A).2. Biocide Ore+ mix. ore (B).3 .Bentocide ore+ mix. ore (D).4 . (Biophertel ore and Biocide Ore $)+$ mix. Ore $(A+B) .5$. (Bio phertelore and Bentocideore ) + mix. Ore $(A+D) .6$. ( Biocide ore and Bentocide ore) + mix. Ore $(B+D) .7$. (Biophertel ore and Biocide ore and Bentocide ore)+ mix. Ore $(A+B+D)$. 8. Treatment without any spray (mix. ore only). 9. Control . 


\begin{tabular}{|c|c|c|c|c|}
\hline \multirow{6}{*}{ 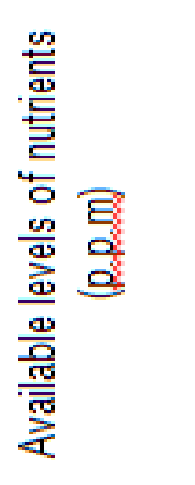 } & \multicolumn{2}{|r|}{$z+n O$} & $\mathrm{OZ} \cdot \mathrm{O}$ & SZ'o \\
\hline & \multicolumn{2}{|r|}{$z+\mathrm{U} / \mathrm{N}$} & $\angle O$ & 8.0 \\
\hline & \multicolumn{2}{|r|}{$z+u z$} & $9 \varepsilon^{\circ} 0$ & $9 \varepsilon^{\circ} 0$ \\
\hline & \multicolumn{2}{|r|}{$\left.2+^{\theta}\right\rfloor$} & SZO & $\mathrm{OZ} \cdot \mathrm{O}$ \\
\hline & \multicolumn{2}{|r|}{$1+\lambda 1$} & OS'O & $99^{\circ} 0$ \\
\hline & \multicolumn{2}{|r|}{$-\varepsilon d$} & $60^{\circ} \mathrm{L}$ & $O Z \cdot$ \\
\hline \multicolumn{3}{|c|}{$\%$ عojeo } & $8^{\prime} \varepsilon$ & $6 \cdot \varepsilon$ \\
\hline \multicolumn{3}{|c|}{$\%$ NO } & $98^{\circ} 0$ & $08^{\circ} 0$ \\
\hline \multirow{6}{*}{ 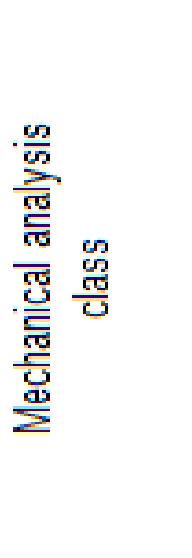 } & \multicolumn{2}{|c|}{ 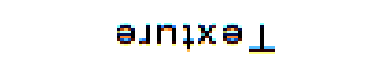 } & pues & pues \\
\hline & \multicolumn{2}{|r|}{$\% d S$} & $\triangleright 乙$ & $\triangleright \tau$ \\
\hline & \multirow{3}{*}{ 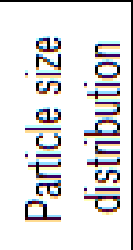 } & $\%$ રері & $t \cdot L$ & $t \cdot r$ \\
\hline & & $\%$ HI!S & 91 & 9.1 \\
\hline & & $\%$ pues & $0: \angle 6$ & $0: \angle 6$ \\
\hline & $\begin{array}{l}\text { 恕 } \\
\text { 芯 }\end{array}$ & \% ן ן & $8^{\circ} \varepsilon$ & $6 \cdot \varepsilon$ \\
\hline \multicolumn{3}{|c|}{ ¿্বS } & $\nabla \cdot 9$ & $9 \cdot 9$ \\
\hline \multirow{3}{*}{ 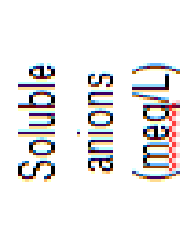 } & \multicolumn{2}{|c|}{$1-{ }^{\varepsilon} \mathrm{O} O \mathrm{H}$} & $0 \angle 0$ & $S \angle 0$ \\
\hline & \multicolumn{2}{|c|}{$z^{-\infty}$ OS } & $o \varepsilon \cdot t$ & $S \angle D$ \\
\hline & \multicolumn{2}{|r|}{-10} & $08 \%$ & $0 \angle D$ \\
\hline \multirow{4}{*}{ 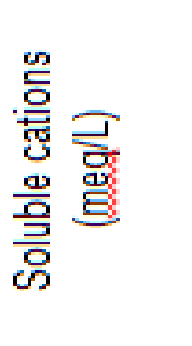 } & \multicolumn{2}{|r|}{$z+$ eo } & $00^{\circ} \varepsilon$ & $o{ }^{\prime} \varepsilon$ \\
\hline & \multicolumn{2}{|r|}{$L=e N$} & $o \varepsilon \cdot t$ & SLt \\
\hline & \multicolumn{2}{|r|}{$1+21$} & OSO & $99^{\circ} 0$ \\
\hline & \multicolumn{2}{|r|}{$z+6 \mathrm{w}$} & $00^{\prime} 乙$ & SL乙 \\
\hline \multicolumn{3}{|c|}{$\mathrm{H}^{\mathrm{d}}$} & Zl' $\angle$ & $\varepsilon \varepsilon^{\prime} \angle$ \\
\hline \multicolumn{3}{|c|}{ (W/SP) $\quad$ } & $86^{\circ} 0$ & $\angle 6^{\circ} 0$ \\
\hline \multicolumn{3}{|c|}{ uoseas } & ยLOZ/ZLOZ & †LOZ/ELOZ \\
\hline
\end{tabular}




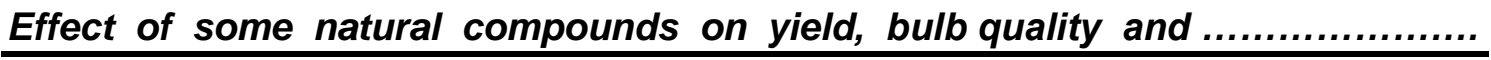

Table (2): Water chemidal analysis of the

two experimental 2012/2013\&2013/2014.

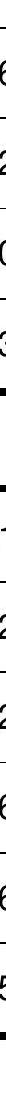


Arafa, et al.,

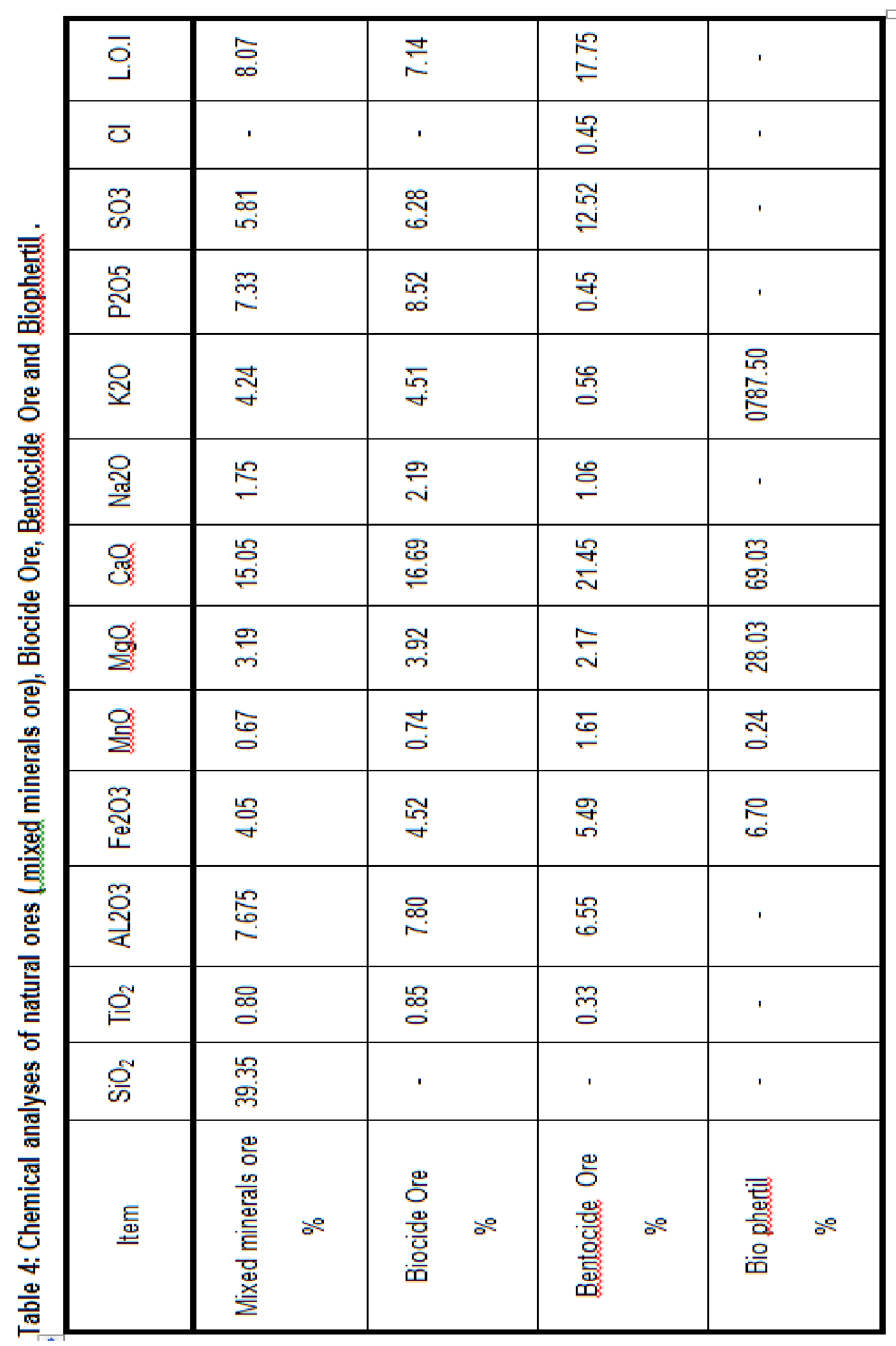


The plants were grown in the field on ridges of $90 \mathrm{~cm}$ width at $10 \mathrm{~cm}$ apart. The agriculture practices were done as commonly followed in the district. Harvesting was done when $50 \%$ of plants foliage were bended done showing symptoms of ripening. The two cvs were harvested at 25th May during both seasons.

\section{Phytopathology (Downy mildew, purple blotch and onion bulb yield assessment):}

Disease severity of downy mildew was recorded after two and three months from planting (at first week of February and March), while purple blotch was recorded after three and four month from planting (at first week of March and April) according to favorable weather conditions for each causal pathogen of downy mildew or purple blotch disease. One hundred leaves from each plot were chosen as randomized samples to determine disease severity of both studied diseases.

All data of each experiment were statistically analyzed according to the technique of variance (ANOVA) for the strip plot design as published by Gomez and Gomez (1984), using "MSTAT-C" Computer software package. least Significant Difference (L.S.D) method was used to test the differences between treatment means at $5 \%$ level of probability as described Snedecor and Cochran (1980).

\section{RESULTS AND DISCUSSION \\ 1- Yield and its components}

Data in Table 5 reveal that, the produced yield and its components, i.e. fresh weight, dry weight of bulbs, total and marketable yield per fed. were not significantly affected among the tested cultivars during both seasons of growth.In this respect, cv. Giza 20gave the highest values in most measured character compared with cv. Giza Red, during both seasons 2013 and 2014.
Such differences reached the level of significantly only in case of total yield in the first seasons and marketable yield in the second one. Where cv. Giza 20 gave the highest total bulb yield, while Giza Red gave the highest marketable yield. These differences may be attributed to the genetic potential of tested cultivars. Those results are in agreement with those reported by Mostafa and Abd El-Megid (1998), AboKoreen and Arafa (2005), Surviliene et al. (2008) and Soleymani and Shahrajabian (2012) .

With respect to the effects of the different adding soil and foliar applications of natural mixer ores on the yield and its components, data in Table 5 show that all measured yield parameters were significantly increased with adding natural mixed ores as a soil or foliar applications than the control. This result were true in both seasons. These increases in total bulbs yield by $(\mathrm{abd}+\mathrm{mix})$ fertilizers over than the control might be attributed to the role of nitrogen on chlorophyll, enzymes and protein synthesizes and the role of phosphorous on root growth and development as well as the role of potassium on promotion of enzymes activity and enhancing the translocation of assimilates.Also may be due to the role of organic manures which are valuable as a source of many essential macro and micronutrients nutrient to plants and serves as a good natural soil texture conditioner being rich in organic matter and increase availability and uptake of nitrogen, phosphorus and potassium which positively reflected on plant cell division and elongation and division as well as stimulate photosynthesis and metabolic processes of organic compounds in plant, thus increasing total bulbs yield/fed. These results are in the same line with those reported by Lakra, 1999, Jayakumar et al. (2008), Abd ELSalam et al. (2005), Al-hefny et al., (2008), Kandil et al. (2010) and Salem (2012) . 
As for the interaction among cultivars and natural mixed ores on the yield and its components, data in Table 5 show that all parameters of yield are not significantly affected in both seasons.

\section{2- Bulbs quality}

As for the effect of the two studied cultivars, data presented in Table 6 reveal that, the cv. Giza 20 gave the highest values of mean shape index than cv. Giza Red, while number of episodes circular and T.S.S $\%$ characters are not significant between the two cvs. this was true during both seasons i.e., 2013 and 2014. These results are agreeable with those reported by Mostafa and Abd El-Megid (1998) and Kandil et al. (2010) .

The same data in Table 6 show that, the mixed ores and the control treatments gave the highest value of bulb quality i.e., mean shape index, this is true during both seasons, while number of episodes circular and T.S.S \% characters are significantly increased with abd+mix. treatment, during both seasons. These results are in agreement with those reported by Salem (2012) .

Similar results were obtained by Moursy et al. (2007) indicated that, such increases in TSS \% due to addition of mineral NPK fertilizers and macro elements may be attributed to the role of $\mathrm{P}$ and $\mathrm{K}$ together with nitrogen in increases the metabolic components synthesized by the plant which reflected on a better growth and increasing dry matter accumulation and total soluble solids percentage in bulbs.

Concerning, the influence of the interaction, data in Table 6 show that, cultivars in combination with natural mixed ores as effected bulbs quality showed no significantlyresponse in both growing seasons.

\section{3- Chemical composition of bulbs}

Concerning the effect of cultivars on chemical contents of bulbs data in Table 7 indicate that, the mineral content of bulbs was significantly affected by the used cultivars. It is evident that cv. Giza 20 gave the highest values of $P$ and $K$ content of bulbs than cv. Giza Red, while N,total carbohydrates percentage in the second seasons and total protein percentage were not significantly affected by cvs., this results were true in both seasons. These results are in the same line with those reported by Soleymani and Shahrajabian (2012). The same data in Table7 indicate that, adding the abd+mix. treatment significantly gave the high concentration of macro ( $N, P$ and $K$ ), total carbohydrates percentage and total protein percentage of bulbs during both seasons of study, in this respect, the increase in $\mathrm{N}$ contents in bulbs as a result of phosphorus application might be due to its role in production of nucleic acids and enzyme as NAD, NAD P, FAD and ATP. These results are in agreement with those reported by AbdEl-Al (2003) and Abd ELSalam et al. (2005).

Data in Table 7 indicate also that, mineral content of bulbs was not significantly affected by the interaction between cvs and natural ores treatments, during both of this study.

\section{4- phytopathology}

Natural ores at 60 and 90 days downy mildew and 90 and 120 on days purple blotch after

Data presented in Table 8 show that, the main effect of two cultivars at onion of 60 and 90 days on downy mildew and at 90 and 120 days on purple blotch after transplanting in the two growing seasons of 2013 and 2014 , the data of the comparison among the values indicate no significant differences were found among the tested cultivars except in case of purple blotch in the second season after 120 days from transplanting where cv. Giza Red reflected the highest values for infected bulbs. between them during both seasons. 


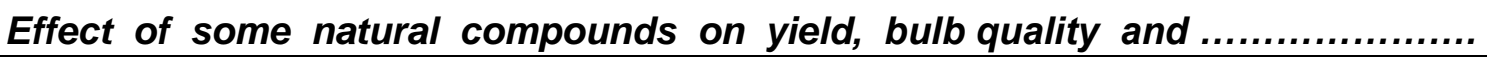

\begin{tabular}{|c|c|c|c|c|c|c|c|c|c|c|c|c|}
\hline \multirow{2}{*}{ 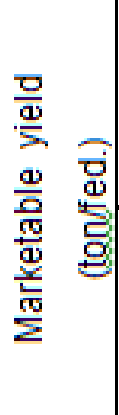 } & 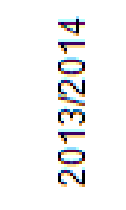 & $\begin{array}{l}\text { Oे } \\
\text { กิ } \\
\text { ஸें }\end{array}$ & $\begin{array}{l}\text { 옹 } \\
\text { 을 } \\
\text { స̃ }\end{array}$ & 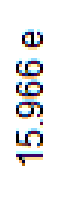 & $\begin{array}{l}0 \\
\stackrel{N}{N} \\
\tilde{N}\end{array}$ & 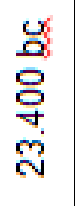 & $\begin{array}{l}\frac{y}{8} \\
\stackrel{0}{O} \\
\text { N }\end{array}$ & 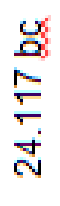 & $\begin{array}{l}\stackrel{0}{m} \\
\stackrel{M}{N} \\
\text { d }\end{array}$ & $\begin{array}{l}y \\
8 \\
8 \\
0 \\
\text { d }\end{array}$ & $\begin{array}{l}\pi \\
\stackrel{\circ}{~} \\
\text { N̦ }\end{array}$ & 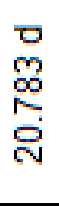 \\
\hline & $\begin{array}{l}\frac{m}{\circ} \\
\stackrel{ }{N} \\
\stackrel{ }{\circ}\end{array}$ & $\begin{array}{l}\stackrel{\pi}{~} \\
\stackrel{N}{N} \\
\end{array}$ & $\begin{array}{l}\pi \\
\omega \\
\infty \\
\text { ஸे } \\
\text { लె }\end{array}$ & $\begin{array}{l}0 \\
\stackrel{0}{\infty} \\
\stackrel{\infty}{\infty}\end{array}$ & 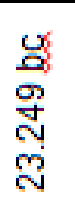 & $\begin{array}{l}\text { 옹 } \\
\text { 올 }\end{array}$ & 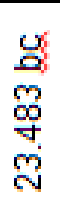 & $\begin{array}{l}\stackrel{0}{\circ} \\
\stackrel{\circ}{\sigma} \\
\stackrel{\text { ஸे }}{ }\end{array}$ & 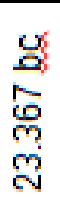 & 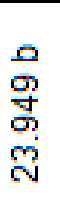 & 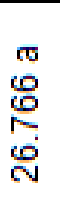 & $\begin{array}{c}\dot{0} \\
\stackrel{m}{\infty} \\
\stackrel{\aleph}{N}\end{array}$ \\
\hline \multirow{2}{*}{ 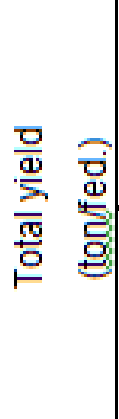 } & 啇 & $\begin{array}{l}\text { os } \\
\text { Nิ } \\
\text { ஸे }\end{array}$ & $\frac{\sigma}{\oplus}$ & 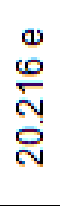 & $\begin{array}{l}0 \\
\stackrel{\circ}{\circ} \\
\stackrel{0}{\circ}\end{array}$ & 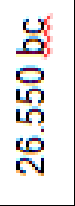 & $\begin{array}{l}\text { 웅 } \\
\stackrel{8}{\circ} \\
\stackrel{0}{0}\end{array}$ & 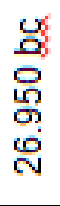 & $\begin{array}{l}0 \\
\frac{1}{2} \\
0 \\
\\
\end{array}$ & 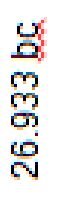 & 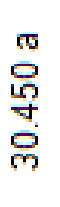 & 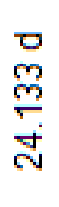 \\
\hline & $\frac{\stackrel{m}{\circ}}{\stackrel{N}{\vdots}}$ & $\begin{array}{l}\text { o } \\
\stackrel{5}{\circ} \\
\stackrel{d}{N}\end{array}$ & 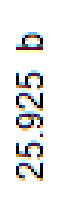 & 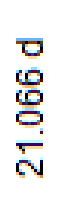 & $\begin{array}{l}0 \\
\stackrel{0}{0} \\
\stackrel{0}{0} \\
\stackrel{0}{ }\end{array}$ & $\begin{array}{l}0 \\
\text { 웅 } \\
\text { ํ. }\end{array}$ & 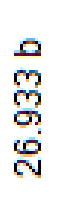 & $\stackrel{\oplus}{\stackrel{0}{m}}$ & $\begin{array}{l}\text { 옹 } \\
\text { 웅 } \\
\stackrel{0}{N}\end{array}$ & $\begin{array}{l}\stackrel{0}{ } \\
\stackrel{\circ}{\sigma} \\
\stackrel{0}{\sim}\end{array}$ & \begin{tabular}{l}
$\sigma$ \\
$m$ \\
$\infty$ \\
0 \\
0 \\
\hdashline
\end{tabular} & $\begin{array}{l}\dot{u} \\
\stackrel{0}{m} \\
\stackrel{m}{d}\end{array}$ \\
\hline \multirow{2}{*}{ 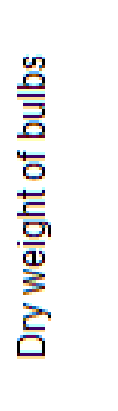 } & 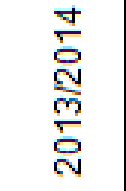 & $\underset{\infty}{\stackrel{\infty}{\infty}}$ & $\underset{\infty}{\stackrel{\pi}{\sigma}}$ & $\begin{array}{l}0 \\
\text { 号 } \\
\text { o }\end{array}$ & \begin{tabular}{l}
0 \\
\multirow{J}{*}{} \\
$\infty$ \\
$\infty$
\end{tabular} & $\begin{array}{l}\frac{0}{0} \\
\frac{2}{0} \\
\stackrel{0}{\sigma} \\
\frac{1}{\infty}\end{array}$ & $E_{\infty}^{\infty}$ & $\begin{array}{l}\text { 어 } \\
\infty \\
\text { N } \\
\infty \\
\infty\end{array}$ & $\begin{array}{l}\stackrel{0}{\pi} \\
\stackrel{2}{0} \\
\infty \\
\infty\end{array}$ & $\begin{array}{l}\frac{y}{3} \\
\frac{3}{0} \\
\frac{0}{5} \\
\frac{0}{\infty}\end{array}$ & $\begin{array}{l}0 \\
\infty \\
\vdots \\
\infty \\
\end{array}$ & $\begin{array}{l}\stackrel{0}{ } \\
\stackrel{0}{0} \\
\stackrel{0}{N}\end{array}$ \\
\hline & 啇 & $\begin{array}{l}\pi \\
\omega \\
\vdots \\
\infty \\
0\end{array}$ & $\stackrel{\substack{n \\
r}}{\stackrel{m}{n}}$ & $\begin{array}{l}\frac{0}{\pi} \\
\frac{m}{1} \\
\end{array}$ & 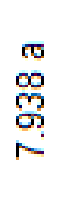 & 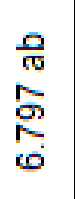 & $\frac{0}{\frac{\pi}{\sigma}}$ & $\begin{array}{l}00 \\
\pi \\
\stackrel{0}{N}\end{array}$ & 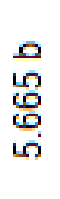 & 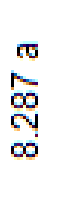 & $\begin{array}{l}\text { 음 } \\
\text { No } \\
N\end{array}$ & $\begin{array}{l}\text { 오 } \\
\infty \\
\infty \\
0 \\
\end{array}$ \\
\hline \multirow{2}{*}{ 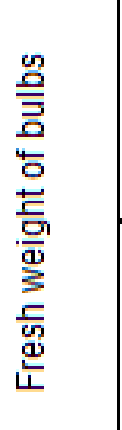 } & 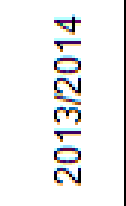 & 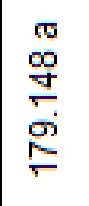 & $\begin{array}{l}\sigma \\
5 \\
0 \\
0 \\
\infty \\
\infty \\
-\end{array}$ & $\begin{array}{l}0 \\
8 \\
\frac{8}{1} \\
\text { ㅊ. }\end{array}$ & 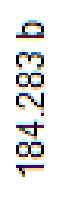 & 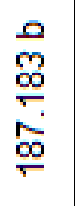 & 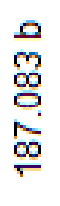 & $\begin{array}{l}0 \\
\pi \\
\circ \\
\varnothing \\
\infty \\
\infty \\
\infty \\
\infty\end{array}$ & 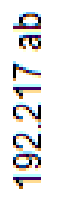 & $\begin{array}{l}\stackrel{0}{0} \\
\frac{\sigma}{v} \\
\stackrel{\circ}{\sigma}\end{array}$ & 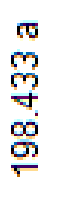 & 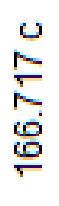 \\
\hline & $\frac{\stackrel{m}{\circ}}{\stackrel{N}{ㅇ ㅡ ㅇ ~}}$ & 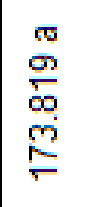 & 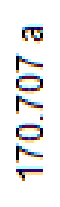 & $\begin{array}{l}\dot{0} \\
\stackrel{m}{N} \\
\stackrel{\oplus}{\leftarrow}\end{array}$ & 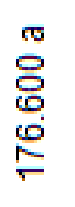 & 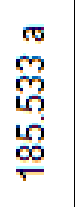 & 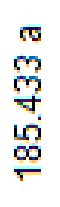 & 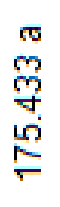 & $\begin{array}{l}\text { ๘ } \\
\stackrel{\circ}{\circ} \\
\text { m. } \\
\stackrel{\circ}{\circ}\end{array}$ & $\begin{array}{l}\pi \\
\stackrel{0}{0} \\
\stackrel{0}{\circ} \\
\stackrel{\sigma}{\sigma}\end{array}$ & $\begin{array}{l}\pi \\
\stackrel{0}{\circ} \\
\stackrel{\circ}{\sigma}\end{array}$ & $\begin{array}{l}\text { 웅 } \\
\text { 오 } \\
\text { 옴 }\end{array}$ \\
\hline \multirow{2}{*}{ 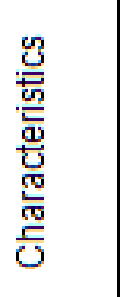 } & \multirow{2}{*}{ 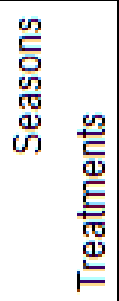 } & $\begin{array}{l}\stackrel{ }{N} \\
\mathbb{N} \\
\text { N }\end{array}$ & $\begin{array}{l}\square \\
\mathbb{\alpha} \\
\widetilde{N} \\
\mathbb{N}\end{array}$ & $\begin{array}{l}\overline{ } \\
\text { 응 }\end{array}$ & 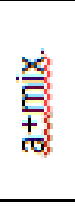 & 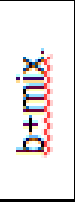 & $\frac{\dot{\phi}}{\stackrel{8}{R}}$ & 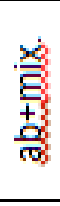 & 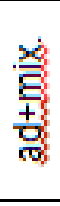 & 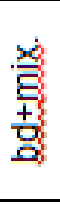 & 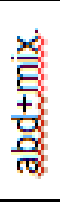 & 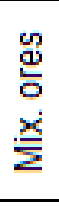 \\
\hline & & \multicolumn{2}{|c|}{ s.es!!łno } & \multicolumn{9}{|c|}{ 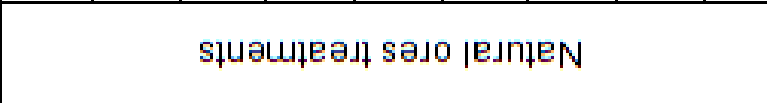 } \\
\hline
\end{tabular}


Arafa, et al.,

\begin{tabular}{|c|c|c|c|c|c|c|c|c|c|c|c|c|}
\hline \multirow{2}{*}{$\begin{array}{l}\text { 。̊ } \\
\text { in } \\
\text { ọ } \\
\vdash\end{array}$} & 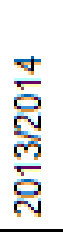 & 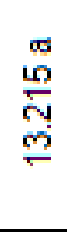 & 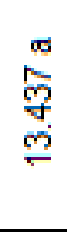 & 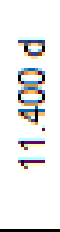 & 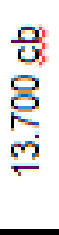 & 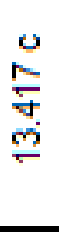 & 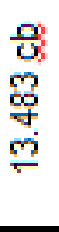 & 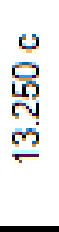 & 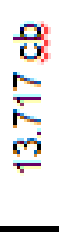 & $\frac{0}{E}$ & 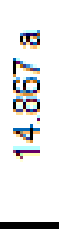 & 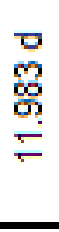 \\
\hline & 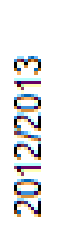 & 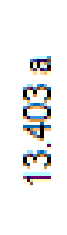 & 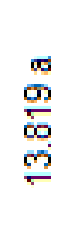 & $\begin{array}{l}\text { 무 } \\
\text { 용 } \\
\text { 둔 }\end{array}$ & 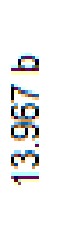 & 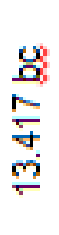 & $\begin{array}{l}\frac{0}{8} \\
\frac{8}{p} \\
\stackrel{m}{-}\end{array}$ & $\begin{array}{l}\text { م) } \\
\stackrel{8}{\infty} \\
\text { లె }\end{array}$ & $\begin{array}{l}\mathscr{8} \\
8 \\
\stackrel{8}{\circ} \\
\text { m. }\end{array}$ & 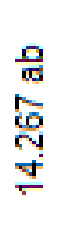 & $\frac{\pi}{\overbrace{}^{\infty}}$ & 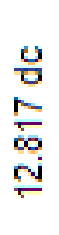 \\
\hline \multirow{2}{*}{ 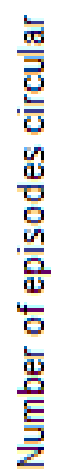 } & 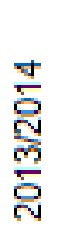 & $\underset{r}{E}$ & 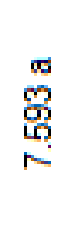 & $\frac{\mathscr{0}}{0}$ & $\begin{array}{l}\frac{\sigma}{\sigma} \\
\frac{0}{\infty} \\
\frac{\infty}{\infty}\end{array}$ & $\begin{array}{l}\text { 워 } \\
8 \\
0 \\
\infty \\
\infty \\
\infty\end{array}$ & 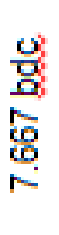 & 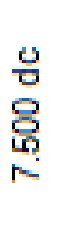 & $\begin{array}{l}0 \\
0 \\
0 \\
0 \\
0\end{array}$ & 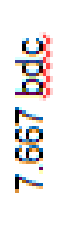 & $\begin{array}{l}\text { ஜீ } \\
\stackrel{\circ}{\circ}\end{array}$ & $\begin{array}{l}\bar{g} \\
\mathbb{d} \\
8 \\
\end{array}$ \\
\hline & 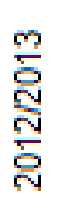 & 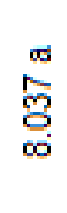 & 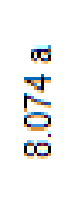 & 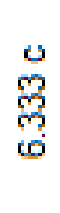 & $\begin{array}{l}\infty \\
\stackrel{0}{0} \\
\infty \\
\infty\end{array}$ & $\begin{array}{l}\varpi \\
\mathcal{M} \\
\infty \\
\infty \\
\infty\end{array}$ & $\begin{array}{l}\infty \\
\mathcal{M} \\
\infty \\
\infty \\
\infty\end{array}$ & $\begin{array}{l}\stackrel{0}{\circ} \\
\stackrel{0}{0} \\
\end{array}$ & $\begin{array}{l}\text { 우 } \\
8 \\
8 \\
\infty \\
\infty\end{array}$ & $\begin{array}{l}\infty \\
\stackrel{0}{\mathscr{O}} \\
\infty \\
\infty\end{array}$ & $\begin{array}{l}\text { 우 } \\
8 \\
8 \\
\varnothing \\
\infty\end{array}$ & 웅 \\
\hline \multirow{2}{*}{ 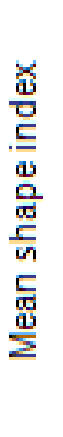 } & 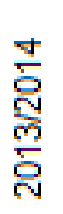 & 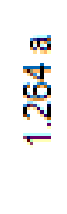 & 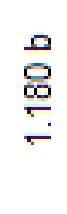 & $\stackrel{\text { }}{\text { ర్ల }}$ & 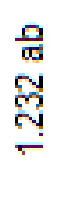 & 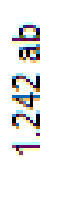 & $\begin{array}{l}\stackrel{0}{\circ} \\
\stackrel{\circ}{\circ} \\
\stackrel{-}{-}\end{array}$ & 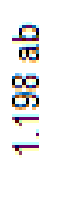 & $\begin{array}{l}\text { 우 } \\
\text { \% } \\
\stackrel{\circ}{-} \\
\end{array}$ & $\begin{array}{l}\text { 우 } \\
\text { 움 } \\
\stackrel{-}{-}\end{array}$ & 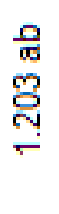 & 承 \\
\hline & 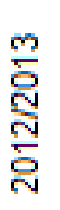 & 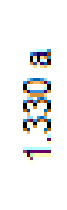 & 웅 & 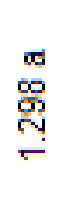 & 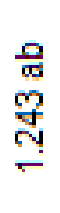 & $\begin{array}{l}\frac{8}{\sigma} \\
\stackrel{8}{8} \\
\stackrel{-}{ }\end{array}$ & 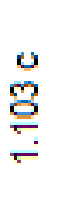 & $\begin{array}{l}\frac{y}{\sigma} \\
\text { 음 } \\
\stackrel{-}{-}\end{array}$ & 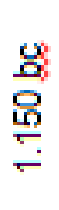 & 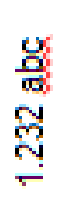 & 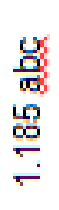 & 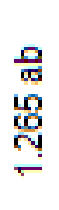 \\
\hline \multirow{2}{*}{ 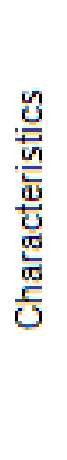 } & & $\begin{array}{l}\text { ㅇ } \\
\text { N } \\
\text { 엉 }\end{array}$ & 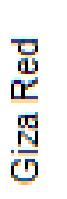 & $\begin{array}{l}\overline{\text { o }} \\
\text { 등 }\end{array}$ & 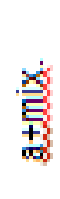 & $\begin{array}{l}\text { 营 } \\
\text { 索 }\end{array}$ & $\begin{array}{l}\text { 离 } \\
\text { 弯 }\end{array}$ & $\begin{array}{l}\text { 尝 } \\
\text { 故 }\end{array}$ & 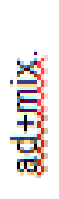 & 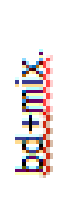 & $\begin{array}{l}\frac{x}{z} \\
\frac{7}{0}\end{array}$ & $\begin{array}{l}\underline{u} \\
\stackrel{0}{0} \\
\dot{x} \\
\dot{\Sigma}\end{array}$ \\
\hline & 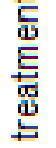 & \multicolumn{2}{|c|}{ sues!nno } & \multicolumn{9}{|c|}{ słuempeal sejo pe.nineN } \\
\hline
\end{tabular}




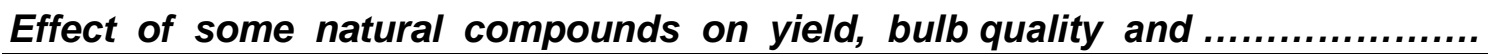

\begin{tabular}{|c|c|c|c|c|c|c|c|c|c|c|c|c|c|}
\hline \multirow{2}{*}{ 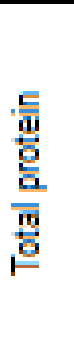 } & \multirow[b]{2}{*}{20} & 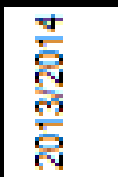 & $\begin{array}{l}m \\
\stackrel{m}{g} \\
\stackrel{g}{0}\end{array}$ & 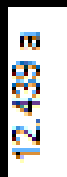 & 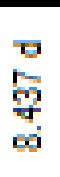 & 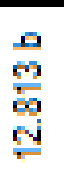 & $\begin{array}{l}\stackrel{0}{\overline{8}} \\
\overline{8} \\
\stackrel{2}{2}\end{array}$ & $\begin{array}{l}\stackrel{0}{E} \\
\underline{E}\end{array}$ & 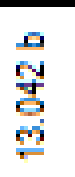 & 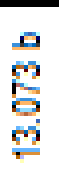 & $\begin{array}{l}\stackrel{0}{ } \\
\stackrel{8}{8} \\
\stackrel{\text { d }}{0}\end{array}$ & 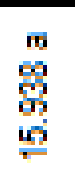 & $\begin{array}{l}0 \\
8 \\
8 \\
0\end{array}$ \\
\hline & & 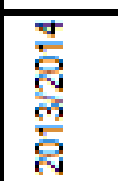 & 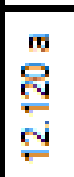 & 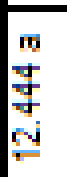 & $\underset{\infty}{\stackrel{a}{E}}$ & 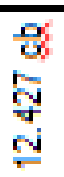 & 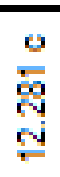 & 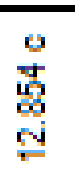 & 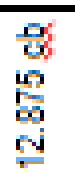 & 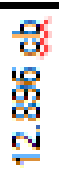 & 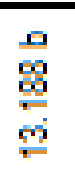 & 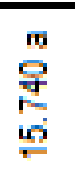 & $\begin{array}{l}\text { 무 } \\
\text { 훙 } \\
\text { 웅 }\end{array}$ \\
\hline \multirow{2}{*}{\multicolumn{2}{|c|}{ 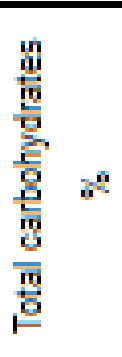 }} & 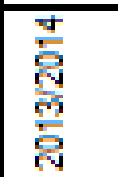 & 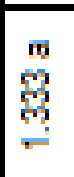 & 党 & $\stackrel{a}{\stackrel{u}{?}}$ & $\begin{array}{l}\frac{8}{6} \\
48 \\
\frac{8}{8} \\
-\end{array}$ & 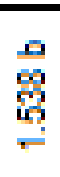 & $\begin{array}{l}\text { \% } \\
\text { 器 } \\
-\end{array}$ & 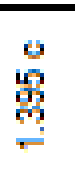 & $\begin{array}{l}\text { \% } \\
\text { 岁 } \\
\text { 岁 }\end{array}$ & 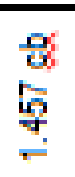 & 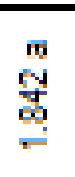 & $\begin{array}{l}\text { 무 } \\
\text { 월 }\end{array}$ \\
\hline & & $\begin{array}{l}\frac{ \pm}{\delta} \\
\frac{\mathrm{d}}{\mathrm{c}} \\
\frac{\mathrm{d}}{\mathrm{d}}\end{array}$ & 욜 & 焉 & $\stackrel{a}{\stackrel{a}{2}}$ & 䎡 & 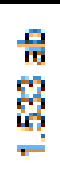 & 。 & 올 & 今ั & $\begin{array}{l}\mathscr{8} \\
\text { go } \\
\text { 告 }\end{array}$ & $\begin{array}{l}m \\
\stackrel{m}{6} \\
\stackrel{m}{6}\end{array}$ & $\begin{array}{l}\text { 웅 } \\
\text { 量 } \\
0\end{array}$ \\
\hline & \multirow{2}{*}{ 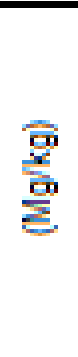 } & 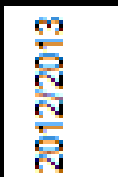 & 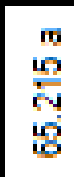 & 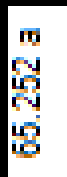 & $\begin{array}{l}\leftarrow \\
\stackrel{5}{\circ} \\
\stackrel{5}{\circ}\end{array}$ & $\begin{array}{l}0 \\
\stackrel{5}{8} \\
8 \\
8\end{array}$ & $\begin{array}{l}\frac{\sigma}{6} \\
8 \\
8 \\
6 \\
8 \\
8\end{array}$ & 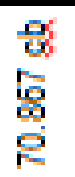 & 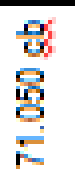 & 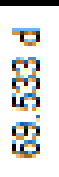 & $\begin{array}{l}\text { 口 } \\
8 \\
8 \\
0\end{array}$ & $\begin{array}{l}m \\
5 \\
5 \\
8 \\
8\end{array}$ & 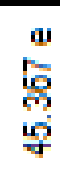 \\
\hline & & 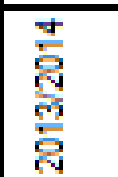 & $\begin{array}{l}m \\
8 \\
8 \\
8 \\
8 \\
8\end{array}$ & 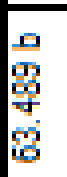 & $\begin{array}{l}\infty \\
\text { 学 } \\
\text { 管 }\end{array}$ & $\begin{array}{l}8 \\
8 \\
50 \\
6 \\
6\end{array}$ & 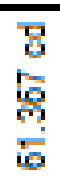 & 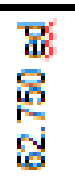 & $\begin{array}{l}\stackrel{0}{8} \\
\stackrel{8}{R} \\
\stackrel{+}{2}\end{array}$ & $\begin{array}{l}\stackrel{0}{\circ} \\
\text { 号 } \\
\text { 용 }\end{array}$ & 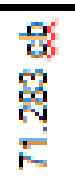 & $\begin{array}{l}m \\
\stackrel{m}{\sigma} \\
\bar{\sigma} \\
\bar{\sigma}\end{array}$ & 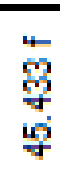 \\
\hline & \multirow{2}{*}{ 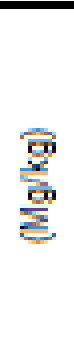 } & $\begin{array}{l}\text { 을 } \\
\text { 월 }\end{array}$ & $\begin{array}{l}m \\
\stackrel{m}{\circ} \\
\stackrel{0}{0} \\
\dot{m}\end{array}$ & م & 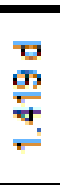 & 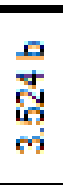 & 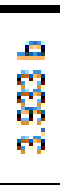 & $\begin{array}{l}\stackrel{0}{\circ} \\
\text { 号 } \\
\text { ̛ }\end{array}$ & 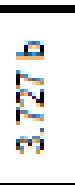 & $\begin{array}{l}\text { 量 } \\
\text { 多 } \\
\text { v }\end{array}$ & $\begin{array}{l}\text { 口 } \\
\text { 吉 } \\
\text { v }\end{array}$ & $\underset{5}{\frac{m}{8}}$ & \begin{tabular}{c}
0 \\
\multirow{0}{0}{} \\
0
\end{tabular} \\
\hline & & 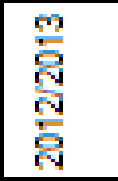 & 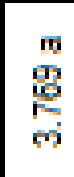 & 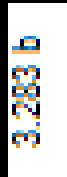 & 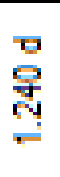 & 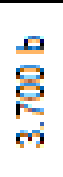 & $\begin{array}{l}\stackrel{a}{g} \\
\text { gु } \\
\text { ले }\end{array}$ & $\begin{array}{l}\text { م } \\
\text { 韋 } \\
\text { ले }\end{array}$ & 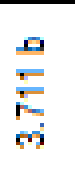 & 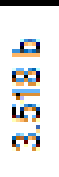 & 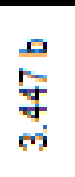 & $\begin{array}{l}m \\
\stackrel{5}{8} \\
r\end{array}$ & 물 \\
\hline \multirow{2}{*}{$z$} & \multirow{2}{*}{ 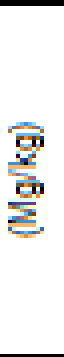 } & 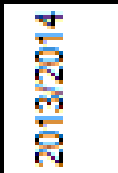 & $\begin{array}{l}\text { m } \\
\text { 喽 } \\
\end{array}$ & m & 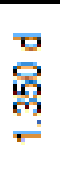 & 옹 & 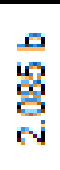 & $\begin{array}{l}\text { D } \\
\text { go } \\
\text { 리 v }\end{array}$ & $\begin{array}{l}0 \\
\text { 总 } \\
\text { N }\end{array}$ & 号 & 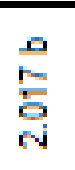 & 曷 & 을 \\
\hline & & 商 & $\begin{array}{l}m \\
\stackrel{m}{g} \\
\stackrel{8}{\sigma} \\
\end{array}$ & $\frac{m}{\bar{d}}$ & 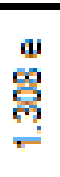 & $\begin{array}{l}\text { 영 } \\
\text { \% } \\
\text { \% } \\
\end{array}$ & $\begin{array}{l}0 \\
\stackrel{8}{8} \\
3 \\
\end{array}$ & 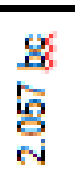 & $\begin{array}{l}\mathscr{8} \\
0 \\
8 \\
8 \\
0\end{array}$ & 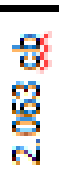 & $\begin{array}{l}\stackrel{0}{\circ} \\
\stackrel{0}{=}\end{array}$ & 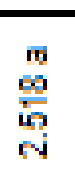 & $\stackrel{0}{10}$ \\
\hline \multirow{2}{*}{\multicolumn{2}{|c|}{ 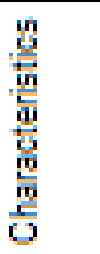 }} & \multirow{2}{*}{ 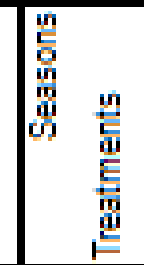 } & 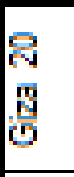 & 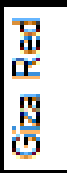 & 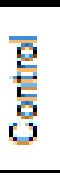 & $\begin{array}{l}\text { 总 } \\
\text { 营 }\end{array}$ & $\begin{array}{l}\text { 岁 } \\
\text { 虽 }\end{array}$ & $\begin{array}{l}\text { 总 } \\
\text { 古 }\end{array}$ & $\begin{array}{l}\text { 总 } \\
\text { 袁 } \\
\text { 营 }\end{array}$ & $\begin{array}{l}\text { 总 } \\
\text { 点 } \\
\text { 莕 }\end{array}$ & $\begin{array}{l}\text { 总 } \\
\text { 点 } \\
\text { 蛋 }\end{array}$ & $\begin{array}{l}\text { 总 } \\
\text { 索 } \\
\text { 营 }\end{array}$ & 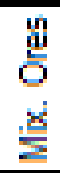 \\
\hline & & & & & & & & & & & & & \\
\hline
\end{tabular}


Arafa, et al.,

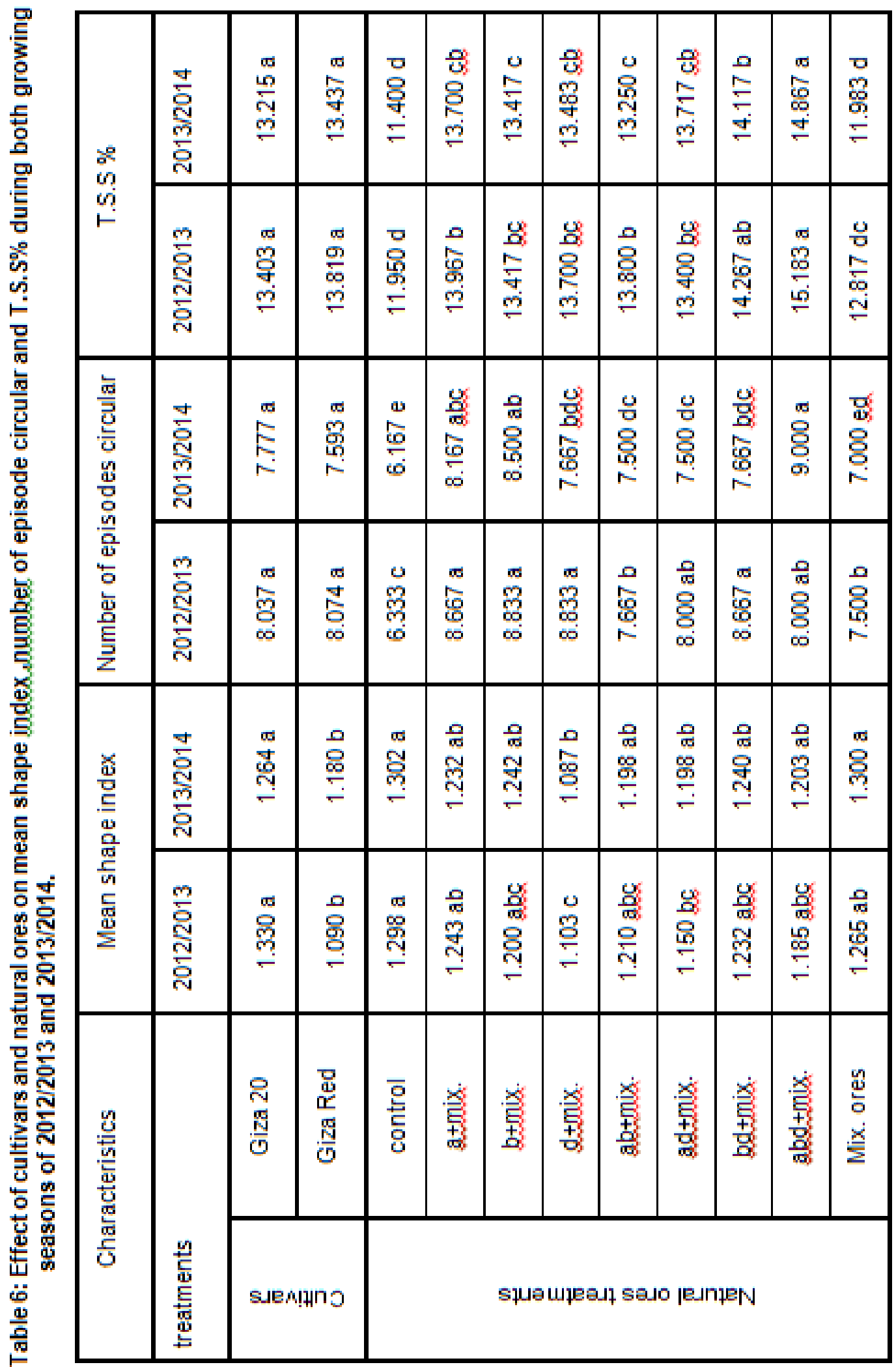


With respect to the effects of the different adding and foliar spraying treatments transplanting, results indicate that added mixer ores and the control comparing with all over the treatments gave the highest values in this respect during both seasons. These results are in agreement with those obtained by Surviliene et al. (2008) and Hoffmann et al. 1996.Similar results were reported by Abd El-Moity et al. (1997) who observed that the downy mildew disease of grain sorghum could be effectively controlled by foliar spray with bio agents $T$. viride ,T.harzianum and Bacillus subtilis. Also Kumar (2007) reported that using the bacterial bio agent $P$. fluorescens was least effective in controlling the spread of purple blotch disease of onion caused by $A$. porri. It is noticed that the efficiency of bio control may be determined by various factors, the soil temperature and soil reaction, the kind of soil and its micro biota, the nutritional status of the inoculants, the inoculums potential of the pathogen in soil and the rate of application of the antagonist to soil .Concerning the effect of the interaction between cultivars and neutral ores, data indicate that, the effects of different adding and foliar spraying treatments natural ores at 60 and 90 days on downy mildew and 90 and 120 on days purple blotch after ttransplanting were not significant a during both seasons of growth.

\section{REFERENCES}

Abd El-al, F. S. (2003). Different nitrogen sources and magnetic iron addition as affected the productivity of eggplant (solanum melogena L. ) plant J.Agric Sci. Mansoura Univ. 28 (4): 2903-2916.

Abdel-Megid, M. S., A. H. Metwally, S. M. Abdel-Momen and A. A. Hilal. (2001). A preliminary field study on the possibility of controlling foliar diseases of onion using some Egyptian medicinal plant extracts in comparison with a fungicide. Egypt. J. Phytopathol. 29, (1): 21-31.
Abd-El-Moity, T. H., A. I. Hanna and M. S. Abdel-Megid (1997). Biological control of downy mildew and purple blotch diseases of onion and garlic under field conditions. Proc. 8th Cong. Egypt. Phytopathol. Soc., 227-242.

Abd EL-Salam, I.Z., M.M. Arafa and O.E. Shalaby (2005). Effect of rock phosphates and rare earth minerals on growth, yield, chemical constituent and active ingredient of the pepper (capsicum annuum L.) under new reclaimed soil conditions. Egypt. J. of Apple. Sci., 20(12) 2005, 285-310.

Abo-Koreen, H. and M. M. Arafa (2005). Effect of different levels of compound fertilizer on two onion cultivars under wady Ghbeen. Annals of Agric. Sci., Moshtohor, Zagazig Univ., 43(4): 1-13.

Al-hefny, E. M., M. A. Ramadan, E. E. Eloksh and M. M. Solyman (2008). Effect of some cultural practices. J. Bio. Chem. Environ. Sci., 3(1): 899-913.

El-Gizy, S. M. (1994). Comparative study for influence of manure sources on growth, yield and pod quality of pea. Menofiya $\mathrm{J}$. Agric. Res., 19(6): 3243-3257.

Gomez, K.A. and A.A. Gomez (1984). Statistical procedures of Agri. Res. 2and Ed . Johon wiley Isons pub.139-153.

Hoffmann, M.P., C.H. Petzoldt and A. C. Frodsham (1996). Integrated pest management for onions. New York State IPM Program Publication: 119 - 78 pp.

Jackson, M. L. (1965). Soil chemical analysis. Printie Hall of India private New Delhi, India.

Javadzadeh, A., A. Ghorbanihagho, S. Bonyadi, M. R. Rashidi, M. Mesgari, N. Rashtchizadeh and H. Argani (2009). Prevention effect of onion juiceon salinity-induced experimental cataract. Ind. J. Ophthalmol., 57:185-189.

Jayakumar, M., K. Ponnuswamy and M. M. Amanullah (2008). Influence of nitrogen and intercropping on pest incidence, yield 
attributes and yield of cotton. J. Applied Sci., 4: 224-228.

Kandil, A. A., A. A. Leilah, A. K. Mostafa and F. H. Fathalla (2010). Study on the internal bulb quality of some new Egyptian onion cultivars under different irrigation regimes. J. of Plant Production, Mansoura Univ., 1(2): 205-212.

Kumar, P. T. (2007). Biological management of (Alternaria blight) of onion. M. Sc. College of Agri., Dharwad Univ. of Agri. Sci., Dharwad. 112 pp.

Lakra, B. S. (1999). Development of purple blotch incited by Alternaria porri and its losses in seed crop of onion (Allium cepa). Indian J. Agric. Sci. , 69 (2): 144146.

(c.f. Rev. PI. Pathol., 78 (11), 1040).

Moursy, M. E. ; H. E. Khalifa ; M.M. Attia ;M. A. Sayed and A. M. Osman (2007).

Effect of organic and nitrogen fertilizers and plant denesities on onion production in sandy soil under drip irrigation system. Alex. J. Agric. Res., 55(1): 103-108.

Mostafa, A.K. and M.S. Abd El-Magid (1998). Evaluation of some onion cultivars to distance severity of downy mildew and purple blotch, bulb yields and quality. J. Agric. Sci. Mansoura Univ., 23 (2): 691-700.

Salem, N. M. I. M. (2012). Effect of organic and mineral fertilization and some foliar treatments on onion yield and quality. M. Sc. Thesis Fac. Of Agric. Mansoura Univ., Egypt.

Sneddecor, G. W. and W. G. Cochran (1980). Statistical methods. 6th ed . lowa State Univ., Press, Ames, Towa, U.S.A.

Singer, S. M., O. M. Sawan, M. M. AbdelMouly and S. R. Salman (1998). Study of the effects of Delta mix TM and organic matter on growth and productivity of bean plants grown under calcareous soil condition. Egypt. J. Hort., 25(3): 335-347.

Soleymani, A. and M. H. Shahrajabian (2012). Effects of different levels of nitrogen on yield and nitrate content of four spring onion genotypes. Inter. J. of Agric. and Crop Sci., 4(4): 179-182.

Surviliene, E., A. Valiuskaite and L. Raudonis (2008). The effect of fungicides on the development of downy mildew of onions. Zemdirbyste Agriculture, 95 (3) :171-179. 
تأثير استخدام بعض الخامات الطبيعية على المحصول والجودة والمقاومة للامراض لصنفين من البصل المنزرعين تحت ظروف الاراضي الرملية

ممدوح محمد عرفة ، هالة احمد عبد العال ، صبري (براهيم شاهين ، مدئ محمود حسن عبد الحكيم الحنفي

قسم التتمية المتواصلة للبيئة وادارة مشروعاتها - معهد الدراسات والبحوث البيئية - جامعة مدينة السادات- مصر .

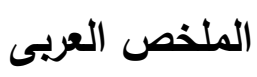

أجريت تجربتان حقليتان في مزرعة معهد الدراسات والبحوث البيئية - جامعة مدينة السادات خلا موسمي 2013 و

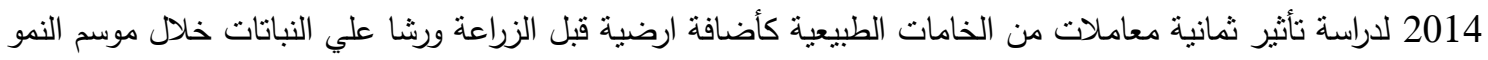

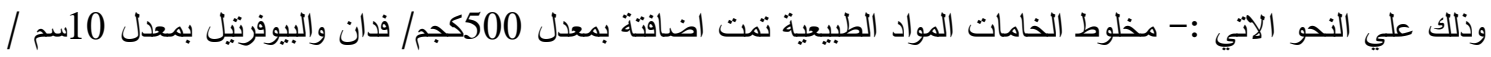
لتز ماء ، البيوسيد بمعدل 5 جم/لتز والبنتوسيد بمعدل 10جم / لنز منفردا او كل أثثين او ثلاثه معا بالإضافة الي معاملة الكنترول (بدون اضافات ) وذلك علي صنفين من البصل هما جيزة 20 و جيزة ريد وليد.

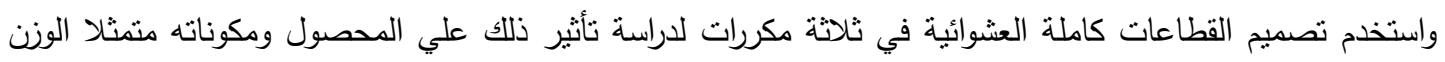

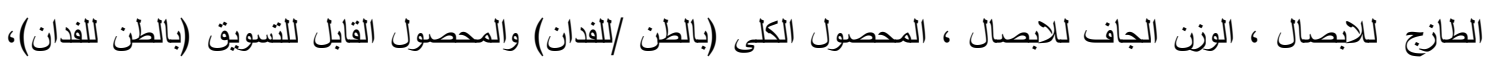
جودة البصال (طول وقطر البصله ، عدد الحلقات الدائريه و النسبه المئوية للمواد الصلبه الذائبه الكليه، الصفات الكيماويه

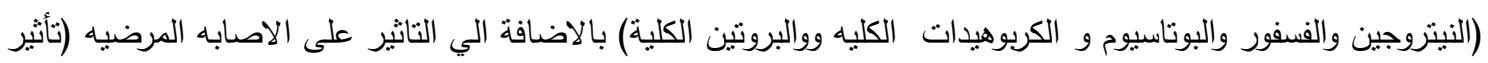
الاصابه بالبياض الزغبى 60عند و 90 يوم من الشتل و تأثثر الاصنابه باللطعه الارجوانيه عند 90 و 120 يوم من الثتل).

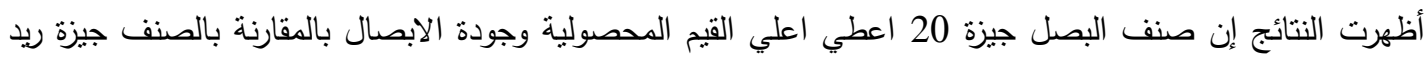

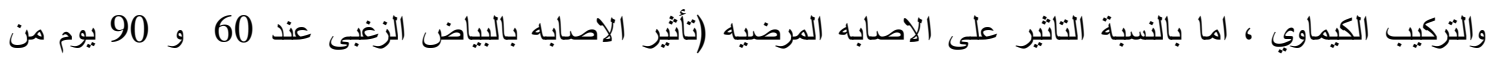

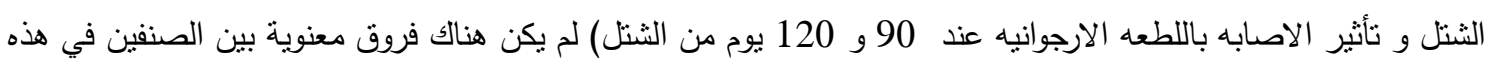
الصفات . الصنات

اما بالنسبة الي معاملات مخلوط الخامات الطبيعية فقد اظهرت النتائج ان استخدام مخلوط الخامات الطبيعية الارضية بالاضافة الي الرش بالمخلوط الثلاثي ( البيوفيرتيل ، البيوسيد و البنتوسيد ) اعطي اعلي القيم للصفات محل الدراسة بالمقارنة بمعاملة الكنترول . اما بالنسبة للتفاعل بين الاصناف ومخلوط الخامات الطبيعية فقد اظهرت النتائج الي عدم وجود فروق معنوية بين

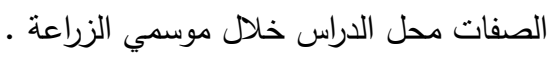

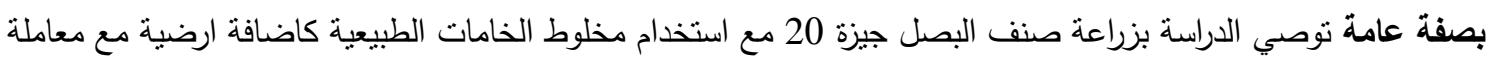

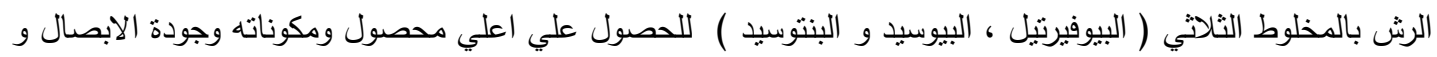

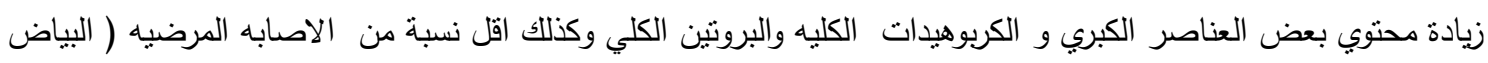
الزغبى بعد 60 و 90 يوم من الثتل و نتأثثر الاصابه باللطعه الارجوانيه عند 90 و 120 يوم من الثنل) .

البريد الالكترونى

E-mail:mujareg@gmail.com
موقع المجلة

Mujareg.blogspot.com 
Arafa, et al., 